\title{
FAKTOR - FAKTOR YANG MENDORONG KEPATUHAN MASYARAKAT KABUPATEN BANTUL UNTUK MEMBAYAR PBB P2
}

\author{
Septian Kurnia Dewi ${ }^{1}$, Amir Hidayatulloh ${ }^{2}$ \\ Universitas Ahmad Dahlan 1,2 \\ Jalan Kapas Nomor 9 Semaki Gede Umbulharjo, Yogyakarta, 55166, Indonesia \\ e-mail: septiankurniadewi1@gmail.com ${ }^{1}$
}

\begin{abstract}
The purpose of this study was to analyze the influence of motivation, morality, and the role of village officials on community compliance in paying rural and urban land and building taxes with tax sanctions as a moderating variable. The population in this study is individual taxpayers who live in Bantul Regency, Yogyakarta Special Region Province. The sample in this study is an individual taxpayer who owns land and buildings domiciled in Bantul Regency. The sampling technique in this study uses purposive sampling, with criteria (1) taxpayers who live in Bantul Regency, and (2) taxpayers who own land and buildings. Data collection in this study used a questionnaire distributed directly to respondents who met the criteria. Respondents in the study numbered 127 respondents. Data analysis techniques in this study used simple regression and Moderated Regression Analysis. This study found that community compliance to pay PBB P2 was influenced by the motivation and role of village officials. Meanwhile, morality has no effect on community compliance to pay PBB P2. The study also obtained the results of the taxation sanski variable moderating the influence of motivation on taxpayer compliance, and moderating the effect of the role of village officials on tax compliance. However, tax sanctions do not moderate the effect of morality on taxpayer compliance to pay PBB P2.
\end{abstract}

Keywords: Motivation; Moralit, The Role of Village Officials, Tax Sanctions, Tax Compliance

\begin{abstract}
Abstrak
Tujuan penelitian ini adalah untuk menganalisis pengaruh motivasi, moralitas, dan peran perangkat desa terhadap kepatuhan masyakar dalam membayar pajak bumi dan bangunan perdesaan dan perkotaan dengan sanksi perpajakan sebagai variabel moderasi. Populasi dalam penelitian adalah wajib pajak orang pribadi yang berdomisili di Kabupaten Bantul provinsi Daerah Istimewa Yogyakarta. Sampel dalam penelitian ini adalah wajib pajak orang pribadi yang memiliki tanah dan bangunan yang berdomisili di Kabupaten Bantul. Teknik pengambilan sampel dalam penelitian ini menggunakan purposive sampling, dengan kriteria (1) wajib pajak yang berdomisili di Kabupaten Bantul, dan (2) wajib pajak yang memiliki tanah dan bangunan. Pengumpulan data dalam penelitian ini menggunakan kuesioner yang disebarkan secara langsung kepada responden yang memenuhi kriteria. Responden dalam penelitian berjumlah 127 responden. Teknik analisis data dalam penelitian ini menggunakan regresi sederhana dan Moderated Regression Analysis. Penelitian ini memperoleh hasil bahwa kepatuhan masyakarat untuk membayar PBB P2 dipengaruhi oleh motivasi dan peran perangkat desa. Sedangkan, moralitas tidak berpengaruh terhadap kepatuhan masyarakat untuk membayar PBB P2. Penelitian juga memperoleh hasil variabel sanski perpajakan memoderasi pengaruh motivasi terhadap kepatuhan wajib pajak, serta memoderasi pengaruh peran perangkat desa pada kepatuhan pajak. Akan tetapi, sanksi perpajakan tidak memoderasi pengaruh moralitas terhadap kepatuhan wajib pajak untuk membayar PBB P2.
\end{abstract}

Kata kunci: Motivasi, Moralitas, Peran Perangkat Desa, Sanksi Perpajakan, Kepatuhan Pajak 
Septian Kurnia Dewi dan Amir Hidayatulloh: Faktor - Faktor yang Mendorong Wajib Pajak Kabupaten Bantul untuk Membayar PBB P2

\section{PENDAHULUAN}

Penerimaan negara berasal dari berbagai sektor, baik sektor internal maupun sektor eksternal. Salah satu sumber internal berasal dari pajak, sedangkan sumber penerimaan negara yang berasal dari eksternal adalah pinjaman luar negeri. Salah satu langkah pemerintah untuk mengurangi sumber penerimaan eksternal adalah dengan memaksimalkan penerimaan internal. Saat ini, pajak merupakan sumber penerimaan internal terbesar pada Anggaran Pendapatan dan Belanja Negara (APBN). Penerimaan negara dari sektor pajak setiap tahunnya mengalami peningkatan. Berikut disajikan proporsi realisasi penerimaan pajak pada APBN tahun 2013 sampai dengan tahun 2017.

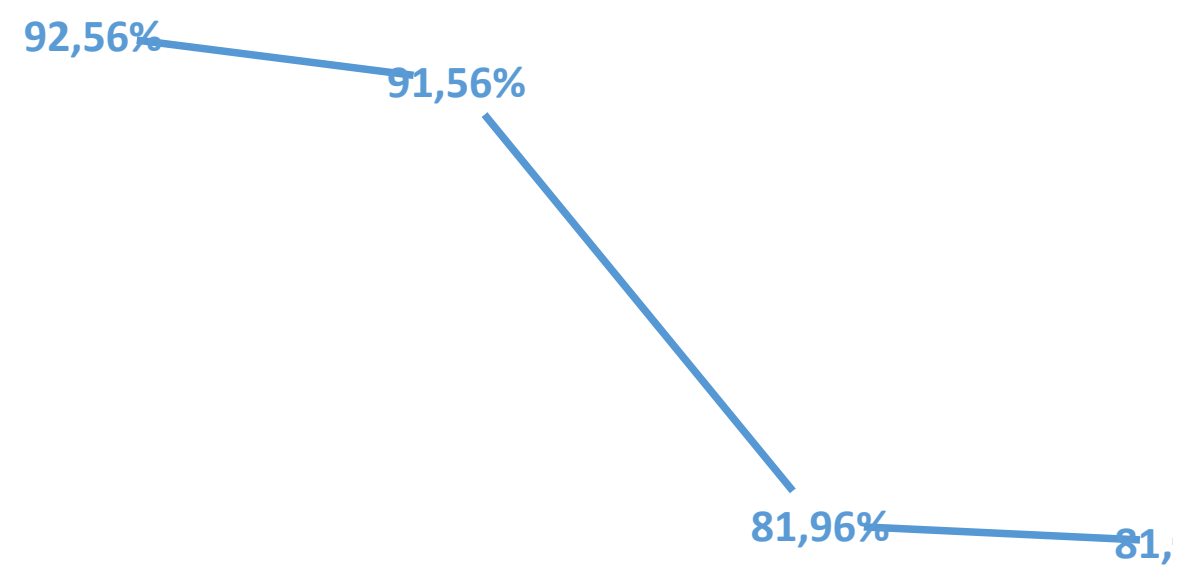

Gambar 1. Realisasi Penerimaan Pajak Tahun 2013-2017

Sumber: Data Primer, diolah (2017) didapat (www.pajak.go.id, 2017)

Gambar 1 menunjukan bahwa persentase capaian penerimaan pajak sampai dengan kuartalan tahun 2017 adalah 89,68 persen lebih besar dibandingkan persentase capaian periode yang sama pada tahun 2016 yaitu 81,60 persen dan pada tahun 2015 yaitu 81,96. Penerimaan dari sektor pajak tahun 2017 mengalami pertumbuhan sebesar 4,08 persen lebih rendah dibandingkan dengan tahun 2016 (4,25 persen). Namun, apabila unsur pengampunan pajak dan revaluasi aktiva tetap dikeluarkan dari porsi penerimaan Negara, maka pada tahun 2017 penerimaan Negara mengalami pertumbuhan 15,8 persen dibandingkan dengan tahun 2016.

Peran pajak yang begitu besar mendorong pemerintah untuk melakukan berbagai upaya guna mencapai target yang telah ditetapkan. Hal ini bertujuan agar permasalahan yang ada pada Direktorat Jenderal pajak (DJP) dan pemerintah berkurang. Salah satu usaha guna mencapai target tersebut yaitu dilakukannya reformasi perpajakan, khususnya reformasi pada peraturan perundang-undangan serta administrasi. Selain itu, upaya lain yang dilakukan pemerintah adalah amandemen perundang-undangan di bidang pajak dan retribusi daerah. Tindakan tersebut merupakan bentuk peran serta pemerintah serta dukungan pelaksanaan otonomi daerah. Oleh karena itu, hubungan sektor keuangan antara pemerintah pusat dan pemerintah pun meningkat. Salah satunya adalah amandemen undang-undang pajak bumi dan bangunan, yaitu Undang-undang Nomor 28 Tahun 2009. 
Menurut (Undang-Undang Nomor 28 Tahun 2009), terjadi pengalihan kegiatan pendataan, penilaian, proses penetapan, kegiatan administrasi hingga pemungutan atau penagihan dan pelayanan PBB yang sebelumnya diselanggarakan oleh pemerintah pusat kemudiaan dialihkan kepada pemerintah daerah. Pengalihan pajak bumi dan bangunan menjadi pajak daerah bertujuan untuk menciptakan kemudahaan dalam pelayanan pajak. Sehingga, kebijakan ini diharapkan dapat meningkatkan penerimaan pajak.

Usaha untuk memaksimalkan penerimaan pajak tidak hanya mengandalkan peran direktorat jenderal pajak maupun petugas pajak. Akan tetapi, juga dibutuhkan peran aktif dari wajib pajak. Peran wajib pajak untuk memenuhi kewajiban pembayaran pajak berdasarkan ketentuan perpajakan sangat diharapkan, sehingga akan diikuti oleh meningkatnya kepatuhan wajib pajak untuk memenuhi kewajiban perpajakannya (Rahayu, 2013).

Motivasi merupakan salah satu faktor yang memengaruhi kepatuhan wajib pajak untuk membayarkan PBB P2 (Husein \& Abdul, 2012); (Putri, 2016). Selain itu, moralitas dan peran perangkat desa juga merupakan faktor yang memengaruhi kepatuhan wajib pajak untuk membayarkan PBB P2. Perangat desa sebagai lembaga yang paling dekat dengan masyarakat memiliki dampak yang besar dalam proses pembangunan dan salah satu sumber pendanaan untuk melakukan pembangunan berasal dari penerimaan pajak. sehingga, perangkat desa dituntut untuk memberikan kesedaran kepada warganya mengenai pentingnya pembayaran pajak, salah satu caranya yaitu dengan memberikan bimbingan, pemahaman, pendekatan, dan sosialisasi kepada masyarakat terkait dengan manfaat dari membayar pajak (Putri, 2016).

Daerah Istimewa Yogyakarta khususnya Kabupaten Bantul tingkat kepatuhan pajak PBB P2 masih tergolong rendah. Pada tahun 2018, tingkat kepatuhan wajib pajak di Kabupaten Bantul baru mencapai 60 persen, bahkan masih ada desa yang capaian pembayarannya masih dibawah lima persen. Hal ini disebabkan oleh beberapa faktor seperti belum maksimalnya penagihan pajak, mulai dari pemilik lahan dan bangunan tidak tinggal di Bantul, surat penagihan pajak terhutang, atau kurangnya peran perangkat desa. Akan tetapi, faktor utama kurangnya kepatuhan wajib pajak yaitu kurangnya kesadaran untuk membayar pajak (yogyakarta.bpk.go.id, 2018). Dari uraian sebelumnya, maka tujuan penelitian ini adalah untuk menganalisis pengaruh motivasi, moralitas, dan peran perangkat desa terhadap kepatuhan masyarakat dalam membayar Pajak Bumi dan Bangunan Perdesaan dan Perkotaan (PBB P2) dengan sanksi perpajakan sebagai variabel moderasi.

\section{KAJIAN PUSTAKA}

\section{Pajak dan Fungsi Pajak}

Pajak merupakan kontribusi wajib warga Negara kepada Negara yang sifat pemungutannya dapat dipaksakan, wajib pajak tidak dapat mendapatkan jasa timbal balik secara langsung dan hasil pemungutan pajak digunakan untuk memenuhi kebutuhan Negara dan kemakmuran masyarakat (Undang-undang Nomor 28, 2007). Pajak memiliki dua fungsi yaitu fungsi angggran dan fungsi pengatur. Fungsi anggaran berarti bahwa pajak digunakan sebagai sumber penerimaan APBN. Sedangkan, fungsi 
Septian Kurnia Dewi dan Amir Hidayatulloh: Faktor - Faktor yang Mendorong Wajib Pajak Kabupaten Bantul untuk Membayar PBB P2

pengatur berarti bahwa pajak digunakan untuk mengatur kehidupan sosial dan ekonomi (Mardiasmo, 2016).

\section{Pajak Bumi dan Bangunan Perdesaan Perkotaan}

Pajak bumi dan bangunan perdesaan dan perkotaan adalah bumi dan/atau bangunan yang dimiliki, dikuasai, dan/atau dimanfaatkan oleh orang pribadi atau badan, kecuali kawasan yang digunakan untuk kegiatan usaha perkebunan, perhutanan, dan pertambangan (Undang-Undang Nomor 28, 2009). Pajak bumi dan bangunan perdesaan dan perkotaan termasuk pajak daerah.

\section{Kepatuhan Wajib Pajak}

Menurut (Peraturan Menteri Keuangan RI Nomor 74/PMK. 03 Tahun 2012), kepatuhan wajib pajak diartikan sebagai kesediaan wajib pajak untuk memenuhi kewajiban perpajakannya yang sesuai dengan aturan yang berlaku tanpa perlu diadakan pemeriksaan, investigasi seksama, peringatan, maupun ancaman. Kepatuhan pada peraturan perpajakan bertujuan untuk meningkatkan keterbukaan administrasi perpajakan dan meningkatkan kepatuhan sukarela wajib pajak (Undang-undang Nomor 28 Tahun 2007). Kepatuhan dalam perpajakan bersifat formal, yaitu kepatuhan mengenai hak dan kewajiban wajib pajak, prosedur serta sanksi perpajakan (Rahman, 2010).

\section{Motivasi Membayar Pajak}

Motivasi membayar pajak merupakan kekuatan potensial yang ada dalam diri wajib pajak yang mendorong wajib pajak untuk membayar pajak. Motivasi timbul dari dalam maupun luar individu. Motivasi yang berasal dari luar adalah adanya dorongan dari aparat pajak, lingkungan kerja, teman atau kerabat yang mendorong wajib pajak untuk membayar pajak (Ghoni, 2014). Lebih lanjut (Ghoni, 2014), indikator-indikator motivasi wajib pajak meliputi motivasi intrinsik dan motivasi ekstrinsik.

Motivasi intrinsik meliputi (1) kejujuran wajib pajak yang terkait dengan self assessment system yang meliputi tingkat kejujuran tinggi dari setiap wajib pajak agar tujuan perpajakan tercapai, (2) kesadaran wajib pajak adalah tingkat kesadaran akan memengaruhi tingkat kepatuhan individu. Sehingga, semakin tinggi tingkat kesadaran wajib pajak untuk memenuhi kewajiban perpajakannya, maka semakin tinggi pula tingkat kepatuhan, dan sebaliknya semakin rendah tingkat kesadaran wajib pajak untuk memenuhi kewajiban perpajakannya, maka semakin rendah pula tingkat kepatuhan, serta (3) hasrat untuk membayar pajak. Kepatuhan akan muncul jika kesadaran dalam membayar pajak diikuti oleh hasrat atau kemauaan yang tinggi dari setiap wajib pajak untuk membayar pajak. Motivasi ekstrinsik meliputi (1) dorongan dari aparat pajak, sosialisasi dari aparat pajak sangat diperlukan. Sosialisasi ini bertujuan agar wajib pajak mengetahui dan memahami kegunaan pajak bagi pembangunan Negara, (2) lingkungan kerja, teman atau kerabat, interaksi sosial antar indivdu dapat mendorong individu untuk melakukan tindakan yang dianggap benar oleh kelompok mayoritas. Sehingga, jika individu berada dalam kelompok taat pajak, maka individu juga akan terdorong untuk taat pajak, dan sebaliknya. Jika individu berada dalam kelompok tidak taat pajak, maka individu juga akan terdorong untuk tidak taat pajak (Ghoni, 2014). 
Septian Kurnia Dewi dan Amir Hidayatulloh: Faktor - Faktor yang Mendorong Wajib Pajak Kabupaten Bantul untuk Membayar PBB P2

\section{Moralitas}

Moral pajak merupakan motivasi intrinsik yang dimiliki wajib pajak untuk membayar pajak yang timbul dari kewajiban moral untuk membayar pajak atau kepercayaan dalam memberikan kontribusi kepada masyarakat dengan membayar pajak (Cuming et al, 2005). Menurut (Andreoni, Erard dan Feinshen, 1998) dalam (Widodo, 2010), faktor moral serta dinamika sosial yang terkait dengan model kepatuhan pajak merupakan area yang belum banyak diteliti. Moralitas pajak dideskripsikan melalui delapan indikator yaitu partisipasi warga Negara, tingkat kepercayaan, otonomi daerah dan desentralisasi, kebanggaan aspek demografis, kondisi ekonomi, aspek pengelakan pajak, dan sistem perpajakan.

\section{Sanksi Perpajakan}

Sanksi perpajakan ada karena adanya sebuah pelanggaran terhadap perundangundangan perpajakan. Sehingga, semakin besar kesalahan yang dilakukan oleh wajib pajak maka semakin berat pula sanksi yang akan diterimanya. Pada undang-undang perpajakan, sanksi dibagi menjadi dua yaitu sanksi administrasi dan sanksi pidana (Resmi, 2014).

Sanksi administrasi diperuntuhkan bagi wajib pajak yang melakukan pelangggaran, khususnya pelanggaran atas kewajiban yang ditentukan pada undangundang ketentuan umum perpajakan. Sanksi administrasi berupa denda, bunga, maupun kenaikan. Sedangkan, sanksi pidana berupa hukuman kurungan atau hukuman penjara. Menurut (Irmawati \& Hidayatulloh, 2019); (Karnedi \& Hidayatulloh, 2019), sanksi perpajakan merupakan salah satu faktor yang memengaruhi kepatuhan wajib pajak.

\section{Peran Perangkat Desa}

Kepemimpinan merupakan kegiatan untuk memengaruhi perilaku orang lain, atau seni memengaruhi perilaku manusia baik perorangan maupun kelompok (Thoha, 1995) dalam (Fachrizal, 2013). Kepemimpinan dapat dipergunakan oleh setiap individu dan tidak terbatas pada perilaku dalam suatu organisasi atau kantor tertentu. Atau dengan kata lain, kepemimpinan dapat terjadi dimana saja, asalkan individu dapat menunjukan kemampuannya untuk memengaruhi perilaku orang lain kearah tercapainya tujuan tertentu.

Pada tingkat desa, seorang kepala desa merupakan wakil dari pemerintahan yang memiliki tugas-tugas serta pelayanan yang cukup berat. Pemerintah desa terus berupaya menata sistem perpajakan nasional. Sistem perpajakan nasional dalam hal ini adalah pencerminan rasa keadilan dan kesadaran menyeluruh. Hal ini berarti pajak dikenakan pada objek pajak baik yang besar maupun kecil serta mengikursertakan lapisan masyarakat (Fachrizal, 2013). 
Septian Kurnia Dewi dan Amir Hidayatulloh: Faktor - Faktor yang Mendorong Wajib Pajak Kabupaten Bantul untuk Membayar PBB P2

\section{HIPOTESIS}

Dari uraian latar belakang dan landasan teori, maka rerangka penelitian ini adalah sebagai berikut:

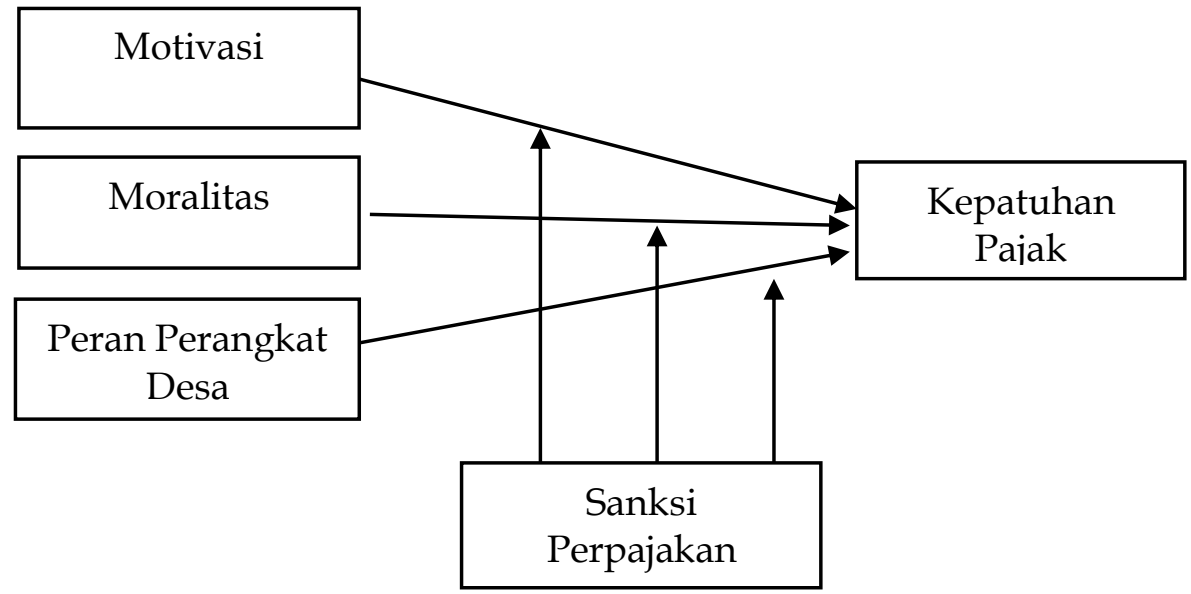

\section{Gambar 1. Rerangka Penelitian}

\section{Pengaruh Motivasi Terhadap Kepatuhan Wajib Pajak}

Ghoni (2014) motivasi membayar pajak adalah suatu kekuatan potensial yang ada dari diri wajib pajak. motivasi dapat mendorong wajib pajak untuk membayar pajak. Motivasi dapat timbul dari dalam individu sendiri maupun luar individu. Motivasi yang berasal dari luar individu meliputi dorongan dari aparat pajak, lingkungan kerja, teman atau kerabat. Lebih lanjut (Ghoni, 2014) menyatakan bahwa semakin tinggi motivasi wajib pajak orang pribadi dalam hal membayar pajak, maka semakin tinggi pula tingkat kepatuhannya. Sehingga, penerimaan pajak oleh direktorat jenderal pajak juga semakin meningkat. Oleh karena itu, hipotesis pertama $\left(\mathrm{H}_{1}\right)$ dalam penelitian ini adalah sebagai berikut:

$\mathrm{H}_{1}$ : motivasi berpengaruh terhadap kepatuhan wajib pajak

\section{Pengaruh Moralitas Terhadap Kepatuhan Wajib Pajak}

Moral pajak merupakan salah satu bentuk motivasi intrinsik untuk membayar pajak. Moral pajak merupakan motivasi intrinsik untuk mematuhi dan membayar pajak. sehingga, wajib pajak dapat berkontribusi secara sukarela pada penyediaan barang publik. Moral pajak merupakan salah satu penentu orang yang jujur dalam masalah perpajakan (Togler, 2007) dalam (Cahyonowati, 2011).

Keputusan moral terutama dipengaruhi oleh perlakuan pada sanksi terhadap tingkat penalaran moral yang rendah, pengharapan akan adanya keadilan pada tingkat moderat, dan masalah keadilan pada tingkat yang tertinggi. Oleh karena itu, wajib pajak yang menggunakan moral dalam pengambilan keputusan pembayaran pajak akan lebih patuh dibandingkan dengan wajib pajak lainnya, sehingga semakin tinggi moral wajib pajak maka semakin tinggi pula kepatuhan membayar pajaknya (Jayanto, 2011). Oleh karena itu, hipotesis kedua $\left(\mathrm{H}_{2}\right)$ penelitian ini adalah sebagai berikut:

$\mathrm{H}_{2}$ : moralitas berpengaruh terhadap kepatuhan wajib pajak 
Septian Kurnia Dewi dan Amir Hidayatulloh: Faktor - Faktor yang Mendorong Wajib Pajak Kabupaten Bantul untuk Membayar PBB P2

\section{Pengaruh Peran Perangkat Desa Terhadap Kepatuhan Wajib Pajak}

Pada tingkat desa, seorang kepala desa merupakan wakil dari pemerintahaan yang memiliki tugas-tugas serta pelayanan yang cukup berat. Kepada desa berusaha untuk menata sistem perpajakan nasional yang meliputi pencerminan rasa keadilan dan kesadaran menyeluruh. Sehingga, pajak dikenakan atas objek pajak baik yang memiliki skala besar maupun kecil, serta mengikutsertakan lapisan masyarakat (Fachrizal, 2013). Salah satu tugas perangkat desa adalah memungut PBB P2. Pemungutan yang dilakukan oleh perangkat desa ini pun merupakan pelayanan utama. Hal ini karena pelayanan tersebut diberikan sesuai tugas pokok dan fungsi utama yang diberikan organisasi atau unit pelayanan yang bersangkutan (Peraturan Menteri Dalam Negeri Republik Indonesia Nomor 08 Tahun 2015). Hal ini didukung oleh hasil penelitian sebelumnya (Fuadi \& Mangoting, 2013), kualitas pelayanan berpengaruh terhadap kepatuhan wajib pajak. oleh karena itu, hipotesis ketiga $\left(\mathrm{H}_{3}\right)$ penelitian ini adalah sebagai berikut:

$\mathrm{H}_{3}$ : peran perangkat desa berpengaruh terhadap kepatuhan wajib pajak

\section{Pengaruh Sanksi Perpajakan Sebagai Variabel Moderating dalam Hubungan antara} Motivasi dan Kepatuhan Pajak

Menurut (Tjahjono, 2006), sanksi perpajakan merupakan tindakan yang diberikan kepada wajib pajak mapun pejabat yang berhubungan dengan pelanggaran pajak yang dilakukan sengaja maupun alpha. Sanksi perpajakan bertujuan untuk menjamin bahwa ketentuan peraturan perundang-undangan perpajakan dipatuhi. Sehingga, semakin individu mempertimbangkan saksi perpajakan maka mendorong individu untuk bersikap patuh. Hasil penelitian (Arjani, Sulindawati, \& Wahyuni, 2017) menyatakan bahwa sanksi perpajakan memoderasi pengaruh motivasi terhadap kepatuhan masyarakat dalam membayar pajak bumi dan bangunan perdesaan dan perkotaan. Oleh karena itu, hipotesis keempat $\left(\mathrm{H}_{4}\right)$ penelitian ini adalah sebagai berikut:

$\mathrm{H}_{4}$ : pengaruh sanksi perpajakan sebagai variabel moderating dalam hubungan antara motivasi dan kepatuhan pajak

\section{Pengaruh Sanksi Perpajakan Sebagai Variabel Moderating dalam Hubungan antara} Moralitas dan Kepatuhan pajak

Menurut (Widodo, 2010), moralitas pajak adalah motivasi yang muncul dari dalam diri individu untuk membayar pajak. Moralitas pajak dibentuk melalui partisipasi warga Negara, kepercayaan, kebanggan, dan sistem perpajakan. Sehingga, ketika dalam diri wajib pajak sudah tertanan rasa bangga sebagai warga Negara, maka wajib pajak tersebut termotivasi untuk membayar pajak dan terdorong untuk memikirkan keadaan bangsanya. Ketaaan wajib pajak untuk membayar pajak dipengaruhi oleh sikap peduli pada kondisi keuangan Negara serta partisipasi warga Negara yang tinggi diikuti dengan terbukanya pola pikir untuk memajukan negaranya (Widodo, 2010). Kecintaan warga Negara pada negaranya salah satunya dapat diwujudkan dengan membayar pajak. Namun, pada dasarnya motivasi yang dapat memengaruhi wajib pajak adalah sistem perpajakan yang mengandung aspek kemudahan. Oleh karena itu, hipotesis keempat $\left(\mathrm{H}_{5}\right)$ penelitian ini adalah sebagai berikut:

H5: pengaruh sanksi perpajakan sebagai variabel moderating dalam hubungan antara moralitas dan kepatuhan pajak 
Septian Kurnia Dewi dan Amir Hidayatulloh: Faktor - Faktor yang Mendorong Wajib Pajak Kabupaten Bantul untuk Membayar PBB P2

Pengaruh Sanksi Perpajakan Sebagai Variabel Moderating dalam Hubungan antara Peran Perangkat Desa dan Kepatuhan pajak

Kepala desa adalah wakil pemerintahan yang memiliki tugas-tugas dan pelayanan yang cukup berat. Kepala desa merupakan wakil pemerintahan yang berada di desa. Pemerintah desa selalu berusaha untuk menata sistem perpajakan nasional. Sistem perpajakan nasional harus mencerminkan rasa keadilan dan kesadaran menyeluruh. Hal ini berari bahwa pajak dikenakan atas objek pajak baik skala besar maupun skala kecil (Fachrizal, 2013). Menurut (Arjani et al., 2017), peran perangkat desa berpengaruh pada kepatuhan masyarakat dalam membayar pajak bumi dan bangunan perdesaan dan perkotaan. Oleh karena itu, hipotesis keenam $\left(\mathrm{H}_{6}\right)$ penelitian adalah sebagai berikut:

$\mathrm{H}_{6}$ : pengaruh sanksi perpajakan sebagai variabel moderating dalam hubungan antara perangkat desa dan kepatuhan pajak.

\section{METODE}

Populasi dalam penelitian ini adalah wajib pajak orang pribadi yang berdomisili di kabupaten Bantul Daerah Istimewa Yogyakarta. Sampel dalam penelitian ini adalah wajib pajak orang pribadi yang memiliki tanah dan bangunan yang berdomisili di kabupaten Bantul. Teknik pengambilan sampel dalam penelitian ini menggunakan purposive sampling, dengan kriteria (1) wajib pajak yang berdomisili di Kabupaten Bantul, dan (2) wajib pajak yang memiliki tanah dan bangunan. Pengumpulan data dalam penelitian ini menggunakan kuesioner yang disebarkan secara langsung kepada responden yang memenuhi kriteria. Variabel dalam penelitian ini terdiri dari variabel independen (motivasi, moralitas, dan peran perangkat desa), variabel dependen (kepatuhan pajak), dan variabel moderasi (sanksi perpajakan). Definisi operasional dan pengukuran masingmasing disajikan pada tabel 1 . Teknik analisis data dalam penelitian ini menggunakan model persamaan regresi sederhana dan moderated regression analysis (MRA).

Tabel 1. Definisi Operasional dan Pengukuran Variabel

\begin{tabular}{|c|c|c|c|c|}
\hline Variabel & Definisi & Sumber & Pengukuran & Sumber \\
\hline $\begin{array}{l}\text { Kepatuhan } \\
\text { Pajak }\end{array}$ & $\begin{array}{l}\text { Kesediaan wajib } \\
\text { pajak untuk } \\
\text { memenuhi } \\
\text { kewajiban } \\
\text { perpajakannya } \\
\text { yang sesuai } \\
\text { dengan yang } \\
\text { peraturan yan tanpa } \\
\text { berlaku diadakan } \\
\text { perlu pemeriksaan, } \\
\text { investigasi } \\
\text { seksama, } \\
\text { peringatan } \\
\text { maupun } \\
\text { ancaman }\end{array}$ & $\begin{array}{ll}\text { Peraturan } & \\
\text { Menteri } & \\
\text { Keuangan } & \text { RI } \\
\text { Nomor } & \\
74 / \text { PMK. } \quad 03 \\
\text { Tahun 2012) }\end{array}$ & $\begin{array}{l}\text { Lima } \\
\text { pernyataan } \\
\text { dengan } \\
\text { menggunakan } \\
\text { skala likert } \\
\text { lima point }\end{array}$ & (Putri, 2016) \\
\hline Motivasi & $\begin{array}{l}\text { Kekuatan } \\
\text { potensial yang }\end{array}$ & (Ghoni, 2014) & $\begin{array}{l}\text { Sepuluh item } \\
\text { pertanyaan }\end{array}$ & $\begin{array}{l}\text { (Arjani et al., } \\
2017)\end{array}$ \\
\hline
\end{tabular}


Septian Kurnia Dewi dan Amir Hidayatulloh: Faktor - Faktor yang Mendorong Wajib Pajak Kabupaten Bantul untuk Membayar PBB P2

\begin{tabular}{|c|c|c|c|c|}
\hline Variabel & Definisi & Sumber & Pengukuran & Sumber \\
\hline & $\begin{array}{l}\text { ada dalam diri } \\
\text { wajib pajak yang } \\
\text { mendorong } \\
\text { wajib pajak } \\
\text { untuk } \\
\text { melakukan } \\
\text { pembayaran } \\
\text { pajak }\end{array}$ & & $\begin{array}{l}\text { dengan } \\
\text { menggunakan } \\
\text { skala likert } \\
\text { lima poin }\end{array}$ & \\
\hline Moralitas & $\begin{array}{l}\text { Motivasi } \\
\text { intrinsik yang } \\
\text { dimiliki wajib } \\
\text { pajak untuk } \\
\text { membayar pajak } \\
\text { yang timbul dari } \\
\text { kewajiban moral } \\
\text { untuk } \\
\text { membayar pajak } \\
\text { atau kepercayaan } \\
\text { wajib pajak } \\
\text { bahwa dengan } \\
\text { membayar pajak } \\
\text { dapat } \\
\text { berkontribusi ke } \\
\text { masyarakat }\end{array}$ & $\begin{array}{l}\text { (Cuming et al, } \\
2005 \text { ) }\end{array}$ & $\begin{array}{l}\text { Empat } \\
\text { pertanyaan } \\
\text { menggunakan } \\
\text { skala likert } \\
\text { lima poin }\end{array}$ & $\begin{array}{l}\text { (Arjani et al., } \\
2017)\end{array}$ \\
\hline $\begin{array}{l}\text { Peran } \\
\text { Perangkat } \\
\text { Desa }\end{array}$ & $\begin{array}{l}\text { Kepala desa } \\
\text { sebagai wakil } \\
\text { pemerintahan } \\
\text { yang } \\
\text { ditempatkan } \\
\text { pada desa-desa } \\
\text { yang memiliki } \\
\text { tugas-tugas serta } \\
\text { pelayanan yang } \\
\text { cukup berat, } \\
\text { salah satu } \\
\text { tugasnya adalah } \\
\text { menata sistem } \\
\text { perpajakan } \\
\text { nasional }\end{array}$ & $\begin{array}{l}\text { (Fachrizal, } \\
\text { 2013) }\end{array}$ & $\begin{array}{l}\text { Empat } \\
\text { pertanyaan } \\
\text { menggunakan } \\
\text { skala likert } \\
\text { lima poin }\end{array}$ & $\begin{array}{l}\text { (Arjani et al., } \\
2017 \text { ) }\end{array}$ \\
\hline $\begin{array}{l}\text { Sanksi } \\
\text { Perpajakan }\end{array}$ & $\begin{array}{l}\text { Hukuman } \\
\text { negatif kepada } \\
\text { orang yang } \\
\text { melanggar } \\
\text { peraturan } \\
\text { dengan cara } \\
\text { membayar uang }\end{array}$ & $\begin{array}{l}\text { (Jotopurnomo } \\
\text { \& Mangoting, } \\
\text { 2013); } \\
\text { (Irmawati \& } \\
\text { Hidayatulloh, } \\
\text { 2019) }\end{array}$ & $\begin{array}{l}\text { Lima } \\
\text { pertanyaan } \\
\text { menggunakan } \\
\text { skala likert } \\
\text { lima poin }\end{array}$ & $\begin{array}{l}\text { (Arjani et al., } \\
2017 \text { ) }\end{array}$ \\
\hline
\end{tabular}

Sumber: data primer, diolah (2019) 
Septian Kurnia Dewi dan Amir Hidayatulloh: Faktor - Faktor yang Mendorong Wajib Pajak Kabupaten Bantul untuk Membayar PBB P2

\section{HASIL DAN PEMBAHASAN}

Teknik pengumpulan data dalam penelitian ini menggunakan kuesioner yang diberikan secara langsung kepada responden yang memenuhi kriteria. Responden dalam penelitian berjumlah 127 responden. Responden dalam penelitian ini didominasi oleh responden berjenis kelamin laki-laki (77 responden), sedangkan responden berjenis kelamin perempuan sebanyak 50 responden. Usia responden didominasi oleh usia 46-50 tahun (44 responden). Tingkat responden dalam penelitian ini didominasi oleh tingkat pendidikan SMA (65 responden).

Deskripsi usia responden dan tingkat pendidikan responden lebih rinci disajikan pada tabel 2.

Tabel 2. Deskripsi Usia dan Tingkat Pendidikan Responden

\begin{tabular}{|l|c|}
\hline \multicolumn{1}{|c|}{ Usia } & Frekuensi \\
\hline 35-40 Tahun & 14 \\
\hline 41-45 Tahun & 39 \\
\hline 46-50 Tahun & 44 \\
\hline 51-55 Tahun & 23 \\
\hline 56-60 Tahun & 7 \\
\hline Tingkat Pendidikan & 5 \\
\hline SD & 34 \\
\hline SMP & 71 \\
\hline SMA & 17 \\
\hline Sarjana & \\
\hline
\end{tabular}

Sumber: data primer, diolah (2019)

Teknik analisis data dalam penelitian ini menggunakan model persamaan regresi sederhana dan moderated regression analysis (MRA). Hasil pengujian regresi sederhana dan moderated regression analysis (MRA) disajikan pada tabel 3.

Tabel 3. Pengujian MRA

\begin{tabular}{|c|c|c|c|c|}
\hline \multicolumn{2}{|r|}{ Persamaan } & Nilai F (Sig) & $\mathrm{R}^{2}$ & Simpulan \\
\hline \multirow[t]{3}{*}{1} & $\mathrm{Y}=\beta_{0}+\beta_{1} \mathrm{X} 1+\mathrm{e}$ & & \multirow{3}{*}{0,067} & \multirow{3}{*}{ H1 Terdukung } \\
\hline & $\mathrm{Y}=14,829+0,173 \mathrm{X} 1+\mathrm{e}$ & 10,059 & & \\
\hline & Sig. $(0,000)(0,002)$ & Sig. 0,002 & & \\
\hline \multirow[t]{3}{*}{2} & $\begin{array}{l}\mathrm{Y}=\beta_{0}+\beta_{1} \mathrm{X} 1+\beta_{3} \mathrm{X} 4+ \\
\mathrm{e}\end{array}$ & & \multirow{3}{*}{0,172} & \multirow{6}{*}{ H4 Terdukung } \\
\hline & $\begin{array}{l}Y=7,910+0,174 X 1+ \\
0,389 X 4+\mathrm{e}\end{array}$ & 14,046 & & \\
\hline & $\begin{array}{ll}\text { Sig. } & (0,006) \quad(0,001) \\
(0,000) & \end{array}$ & Sig. 0,000 & & \\
\hline \multirow[t]{3}{*}{3} & $\begin{array}{l}\mathrm{Y}=\beta_{0}+\beta_{1} \mathrm{X} 1+\beta_{3} \mathrm{X} 4+ \\
\beta_{4} \mathrm{X} 1^{*} \mathrm{X} 4+\mathrm{e}\end{array}$ & & \multirow{3}{*}{0,289} & \\
\hline & $\begin{array}{l}Y=83,607+2,281+ \\
5,741-0,123 \times 1 * X 4+\mathrm{e}\end{array}$ & 0,000 & & \\
\hline & $\begin{array}{lll}\text { Sig. } & (0,000) & (0,000) \\
(0,000) & (0,000) & \end{array}$ & Sig. 0,000 & & \\
\hline \multirow[t]{2}{*}{4} & $\mathrm{Y}=\beta_{0}+\beta_{2} \mathrm{X} 2+\mathrm{e}$ & & & \multirow{2}{*}{$\begin{array}{l}\mathrm{H} 2 \text { tidak } \\
\text { terdukung }\end{array}$} \\
\hline & $\begin{array}{l}Y=20,779-0,089 X 2+ \\
e\end{array}$ & 0,808 & 0,002 & \\
\hline
\end{tabular}


Septian Kurnia Dewi dan Amir Hidayatulloh: Faktor - Faktor yang Mendorong Wajib Pajak Kabupaten Bantul untuk Membayar PBB P2

\begin{tabular}{|c|c|c|c|c|}
\hline \multicolumn{2}{|r|}{ Persamaan } & Nilai F (Sig) & $\mathrm{R}^{2}$ & \multirow[t]{2}{*}{ Simpulan } \\
\hline & Sig. $(0,000)(0,371)$ & Sig. 0,371 & & \\
\hline \multirow[t]{3}{*}{5} & $\begin{array}{l}\mathrm{Y}=\beta_{0}+\beta_{2} \mathrm{X} 2+\beta_{3} \mathrm{X} 4+ \\
\mathrm{e}\end{array}$ & & \multirow{3}{*}{0,098} & \multirow{6}{*}{$\begin{array}{l}\text { H5 tidak } \\
\text { terdukung }\end{array}$} \\
\hline & $\begin{array}{l}Y=14,397-0,069 \mathrm{X} 2+ \\
0,383 \mathrm{X} 4+\mathrm{e}\end{array}$ & 7,867 & & \\
\hline & $\begin{array}{lll}\operatorname{Sig}_{(0,000)} .(0,000) & (0,465)\end{array}$ & Sig. 0,001 & & \\
\hline \multirow[t]{3}{*}{6} & $\begin{array}{l}Y=\beta_{0}+\beta_{2} \mathrm{X} 2+\beta_{3} \mathrm{X} 4+ \\
\beta_{5} \mathrm{X} 2^{*} \mathrm{X} 4+\mathrm{e}\end{array}$ & & \multirow{3}{*}{0,209} & \\
\hline & $\begin{array}{l}\mathrm{Y}=50,888-3,924 \mathrm{X} 2+ \\
4,113 \mathrm{X} 4+0,220 \times 2 * \mathrm{X} 4 \\
+\mathrm{e}\end{array}$ & 12,110 & & \\
\hline & $\begin{array}{lll}\text { Sig. } & (0,001) & (0,000) \\
(0,000) & (0,000)\end{array}$ & Sig. 0,000 & & \\
\hline \multirow[t]{4}{*}{7} & $\mathrm{Y}=\beta_{0}+\beta_{1} \mathrm{X} 3+\mathrm{e}$ & & \multirow{4}{*}{0,028} & \multirow{4}{*}{ H3 Terdukung } \\
\hline & $Y=18,837+0,208 \times 3+e$ & 4,622 & & \\
\hline & Sig $(0000)(0033)$ & Sig 0033 & & \\
\hline & & & & \\
\hline \multirow[t]{3}{*}{8} & $\begin{array}{l}Y=\beta_{0}+\beta_{2} X 3+\beta_{3} X 4+ \\
\mathrm{e}\end{array}$ & & \multirow[b]{3}{*}{0,116} & \multirow{6}{*}{ H6 Terdukung } \\
\hline & $\begin{array}{l}Y=13,212-0,162 X 3+ \\
0,364 X 4+e\end{array}$ & 9,269 & & \\
\hline & $\operatorname{lig}_{(0,000)} .(0,000) \quad(0,084)$ & 0,000 & & \\
\hline \multirow[t]{3}{*}{9} & $\begin{array}{l}Y=\beta_{0}+\beta_{2} \mathrm{X} 3+\beta_{3} \mathrm{X} 4+ \\
\beta_{5} \mathrm{X} 3^{*} \mathrm{X} 4+\mathrm{e}\end{array}$ & & \multirow{3}{*}{0,121} & \\
\hline & $\begin{array}{l}Y=8,296-1,479 X 3+ \\
1,605 X 4+0,076 X^{*} X 4 \\
+\mathrm{e}\end{array}$ & 6,772 & & \\
\hline & $\begin{array}{lll}\text { Sig. } & (0,621) & (0,150) \\
(0,098) & (0,198) & \end{array}$ & 0,000 & & \\
\hline
\end{tabular}

Sumber: data primer, diolah (2019)

Keterangan:

X1: Motivasi

X2: Moralitas

X3: Peran Perangkat Desa

X4: Sanksi perpajakan

Y: Kepatuhan Wajib Pajak

Persamaan (1) pada tabel 3 digunakan untuk menguji $\mathrm{H}_{1}$. Nilai $\mathrm{R}^{2}$ dari persamaan tersebut adalah 0,067 . Hal ini berarti bahwa variabel motivasi dapat menjelaskan variabel kepatuhan pajak sebesar 6,7 persen, sedangkan 93,3 persen dijelaskan oleh variabel 
indepeden di luar model. Simpulan yang dapat diambil adalah regressor dalam persamaan (1) yaitu motivasi berpengaruh terhadap Kepatuhan Pajak. Nilai t-statistik pada persamaan (1) menunjukkan koefisien pada variabel motivasi sebesar 0,173 dan Signifikasi sebesar 0,000 yang lebih kecil dari 0,05. Hal ini berarti bahwa $\mathrm{H}_{1}$ penelitian ini terdukung, motivasi berpengaruh terhadap kepatuhan pajak. Hal ini berati bahwa semakin tinggi motivasi wajib pajak orang pribadi dalam hal membayar pajak, maka semakin tinggi pula tingkat kepatuhan. Hasil ini mendukung hasil penelitian sebelumnya (Arjani et al., 2017); (Putri, 2016); (Husein \& Abdul, 2012) yang menyatakan bahwa moralitas berpengaruh terhadap kepatuhan masyarakat untuk membayarkan pajaknya.

Persamaan (2) dan (3) pada tabel 3 menunjukan bahwa meningkatnya $\mathrm{R}^{2}$. Pada Tabel 3 menunjukkan nilai signifikansi sanksi perpajakan pada persamaan (2) sebesar 0,0000 lebih kecil pada 0,05. Nilai signifikansi $\beta_{4} \mathrm{X} 1^{*} \mathrm{X} 4$ pada persamaan (3) sebesar 0,0000 lebih kecil pada a (5\%). Bila persamaan (2) $\beta_{3} X 4$ memiliki nilai yang signifikan dan persamaan (3) $\beta_{4} \mathrm{X} 1^{*} \mathrm{X} 4$ signifikan, maka variabel sanksi perpajakan merupakan Semu Moderasi. Hal ini berarti bahwa hipotesis keempat $\left(\mathrm{H}_{4}\right)$ penelitian ini terdukung, sanksi perpajakan memoderasi pengaruh moralitas terhadap kepatuhan wajib pajak. Oleh karena itu, semakin individu mempertimbangkan sanksi perpajakan maka individu tersebut semakin terdorong untuk bersikap patuh. Hasil ini mendukung hasil penelitian sebelumnya (Arjani et al., 2017), sanksi perpajakan memoderasi motivasi dalam memengaruhi kepatuhan pajak.

Persamaan (4) pada tabel 3 menunjukan nilai $\mathrm{R}^{2}$ dari persamaan tersebut adalah 0,002 . Hal ini berarti bahwa variabel moralitas dapat menjelaskan kepatuhan wajib pajak sebesar 0,2 persen, sedangkan 99,8 persen dijelaskan oleh variabel lain di luar model. Persamaan (4) menunjukan signifikasi 0,371 yang lebih besar dibandingkan 0,05, sehingga hipotesis dua $\left(\mathrm{H}_{2}\right)$ penelitian ini tidak terdukung, atau dengan kata lain moralitas tidak berpengaruh terhadap kepatuhan wajib pajak. Menurut teori atribusi, perilaku individu dapat dipengaruh orang lain. Hal ini berarti bahwa individu terpaksa berperilaku karena suatu kondisi, yakin perangkat desa yang mengundang wajib pajak untuk mengikuti penyuluhan dan sosialisasi terkait dengan peraturan perpajakan, sehingga wajib pajak tersebut terpaksa berperilaku sesuai dengan situasi yang telah ditentukan dan bukan karena dorongan moral wajib pajak itu sendiri. Hasil penelitian ini mendukung penelitian sebelumnya (Arjani et al., 2017), yang menyatakan bahwa moralitas tidak berpengaruh terhadap kepatuhan wajib pajak.

Persamaan (5) dan persamaan (6) yang disajikan pada tabel 3 menunjukan peningkatan $R^{2}$, dan signifikasi sanksi perpajakan pada persamaan (5) sebesar 0,0000 lebih kecil pada 0,05. Nilai signifikansi $\beta_{4} \mathrm{X} 1^{*} \mathrm{X} 4$ pada persamaan (3) sebesar 0,0000 lebih kecil pada 0,05. Bila persamaan (5) $\beta_{3} \mathrm{X} 4$ memiliki nilai yang tidak signifikan dan persamaan (6) $\beta_{4} \mathrm{X}^{*} \mathrm{X} 4$ tidak signifikan, maka variabel $\mathrm{X} 4$ merupakan Potensial Moderasi. Hal ini berarti hipotesis ke $\left(\mathrm{H}_{5}\right)$ penelitian ini tidak terdukung, atau dengan kata lain sanksi perpajakan tidak memoderasi pengaruh moralitas terhadap kepatuhan pajak. Hal ini sesuai dengan teori atribusi yang menyatakan perilaku individu dapat dipengaruhi oleh orang lain. Sehingga, individu terpaksa berperilaku karena suatu kondisi, seperti perangkat desa yang mengundang wajib pajak untuk mengikuti 
penyuluhan dan sosialisasi terkait dengan peraturan perpajakan, sehingga wajib pajak berperilaku sesuai dengan situasi yang telah ditentukan dan bukan karena dorongan moral wajib pajak itu sendiri. Hasil penelitian ini mendukung penelitian sebelumnya (Arjani et al., 2017), yang menyatakan sanksi perpajakan tidak memoderasi pengaruh moralitas terhadap kepatuhan wajib pajak.

Persamaan (7) yang disajikan pada tabel 3 menunjukan nilai Nilai $\mathrm{R}^{2}$ dari persamaan tersebut sebesar 0,028. Hal ini berarti bahwa variabel kepatuhan wajib pajak dapat dijelaskan oleh peran perangkat desa sebesar 2,8 persen, sedangkan 97,2 persen dijelaskan oleh variabel lain di luar model. Nilai $t$-statistik pada persamaan (7) menunjukkan signifikasi 0,033 yang lebih kecil dari 0,05. Sehingga, hipotesis ketiga $\left(\mathrm{H}_{3}\right)$ penelitian ini terdukung, yaitu peran perangkat desa berpengaruh pada kepatuhan wajib pajak. Oleh karena itu, perangkat desa dalam pemungutan pajaknya telah melakukan berbagai tindakan untuk memberi stimulus kepada seluruh elemen masyarakat bahwa pembayaran pajak itu adalah kewajiban setiap warga Negara. Hasil tersebut mengindikasikan bahwa peran perangkat desa dapat meningkatkan kepatuhan wajib pajak. Hasil penelitian ini mendukung hasil penelitian sebelumnya (Arjani et al., 2017) yang menyatakan bahwa peran perangkat desa berpengaruh terhadap kepatuhan wajib pajak untuk membayar PBB P2.

Persamaan (8) dan (9) pada tabel 3 menunjukan peningkatan $R^{2}$. Pada tabel menunjukkan nilai signifikansi sanksi perpajakan pada persamaan (8) sebesar 0,0000 lebih kecil pada 0,05. Nilai signifikansi $\beta_{4} \mathrm{X}^{*}{ }^{*} 4$ pada persamaan (9) sebesar 0,198 lebih kecil pada 0,05. Bila persamaan (8) $\beta_{3} \mathrm{X} 4$ memiliki nilai yang signifikan dan persamaan (9) $\beta_{4} \mathrm{X} 1^{*} \mathrm{X} 4$ tidak signifikan, maka variabel $\mathrm{X} 4$ merupakan Prediktor Moderasi. Hal ini berarti hipotesis keenam $\left(\mathrm{H}_{6}\right)$ penelitian ini terdukung. Atau dengan kata lain, sanksi perpajakan memoderasi pengaruh peran perangkat desa terhadap kepatuhan wajib pajak untuk membayar PBB P2. Perangkat desa telah melakukan berbagai tindakan yaitu dengan pemberian stimulus kepada seluruh elemen masyarakat bahwa pembayaran pajak itu adalah kewajiban setiap warga Negara. Selain itu, perangkat desa juga sudah menggunakan strategi dimana penarikan pajak dilakukan ketika masyarakat sudah mendapatkan hasil dari pekerjaannya.

\section{KESIMPULAN}

Faktor motivasi merupakan salah satu faktor yang dapat mendorong kepatuhan masyarakat untuk membayar PBB P2. Hal ini berarti bahwa masyarakat yang memiliki motivasi yang besar untuk membayar pajak, maka tingkat kepatuhan masyarakat untuk membayar PBB P2 semakin besar. Selain itu, kepatuhan masyarakat untuk membayarkan PBB P2 tidak terlepas dari peran perangkat desa. Kepala desa merupakan bagian yang melakukan pemungutan PBB P2. Pemungutan yang dilakukan oleh perangkat desa ini pun merupakan merupakan bentuk pelayanan utama yang diberikan sesuai dengan tugas pokok dan fungsi utama yang diberikan organisasi atau unit pelayanan yang bersangkutan. Penelitian ini juga membuktikan bahwa variabel sanksi perpajakan memoderasi pengaruh motivasi terhadap kepatuhan masyarakat untuk membayar PBB P2, serta sanksi perpajakan juga memoderasi pengaruh peran perangkat desa terhadap kepatuhan masyarakat dalam membayar PBB P2. Sehingga, semakin individu 
mempertimbangkan sanksi perpajakan maka individu tersebut semakin terdorong untuk bersikap patuh serta perangkat desa telah melakukan berbagai upaya guna memberikan stimulus kepada seluruh elemen masyarakat bahwa pajak merupakan bentuk kewajiban warga negara. Selain itu, salah satu strategi perangkat desa yang digunakan guna meningkatkan kepatuhan masyarakat dalam membayar PBB P2 yaitu perangkat desa menarik pajak ketika masyarakat sudah mendapatkan hasil dari pekerjaanya.

Tidak ada penelitian sempurna, penelitian ini memiliki validitas internal rendah. Hal ini disebabkan karena penelitian ini menggunakan metode survei. Sehingga, penelitian selanjutanya dapat menggunakan metode wawancara maupun eksperimen guna memperoleh validitas internal yang tinggi.

\section{DAFTAR PUSTAKA}

Arjani, N. N. S., Sulindawati, N. L. G. E., \& Wahyuni, M. A. (2017). Pengaruh Motivasi, Moralitas, dan Peran Perangkat Desa Terhadap Kepatuhan Masyarakat Dalam Membayar Pajak Bumi dan Bangunan Perdesaan dan Perkotaan Dengan Sanksi Perpajakan Sebagai Variabel Moderasi. Jurnal Ilmiah Mahasiswa Akuntansi UNDIKSHA, 7(1).

Cahyonowati. (2011). Model Moral dan Kepatuhan Perpajakan Wajib Pajak Orang Pribadi. Jurnal Akuntansi Dan Auditing Indonesia, 15(11), 161-177.

Cuming, et al. (2005). Effects of Tax Morale on Tax Compliance: Experimental and Survey Evidence. Andrew Young School of Policy Studies. Switzerland: Georgia State University and University of Tennesse.

Fachrizal, M. (2013). Kepemimpinan Lurah dalam Meningkatkan Kinerja Pegawai. Jurnal Pemerintahan Integratif, 1.

Fuadi, A. O., \& Mangoting, Y. (2013). Pengaruh Kualitas Pelayanan Petugas Pajak, Sanksi Perpajakan dan Biaya Kepatuhan Pajak Terhadap Kepatuhan Wajib Pajak UMKM. Tax \& Accounting Review, 1(1).

Ghoni, A. (2014). Pengaruh Motivasi dan Pengetahuan Wajib Pajak Terhadap Kepatuhan Wajib Pajak Daerah. Jurnal Akuntansi UNESS, 1(1).

Husein, \& Abdul, G. (2012). Pengaruh Motivasi dan Pengetahuan Wajib Pajak terhadap Kepatuhan Wajib Pajak. Jurnal UNESA, 1(1).

Irmawati, J., \& Hidayatulloh, A. (2019). Determinan Kepatuhan Wajib Pajak UMKM di Kota Yogyakarta. Jurnal Sistem Informasi, Keuangan, Auditing Dan Perpajakan, 3(2), $112-121$.

Jayanto, P. Y. (2011). Faktor-Faktor Ketidapatuhan Wajib Pajak. JDM, 2(1).

Jotopurnomo, C., \& Mangoting, Y. (2013). Pengaruh Kessadaran Wajib Pajak, Kualitas Pelayanan Fiskus, Sanksi Perpajakan, Lingkungan Wajib Pajak Berada Terhadap Kepatuhan Wajib Pajak Orang Pribadi di Surabaya. Tax \& Accounting Review, 1(1). 
Karnedi, N. F., \& Hidayatulloh, A. (2019). Pengaruh Kesadaran Perpajakan, Sanksi perpajakan dan Tax Amnesty Terhadap Kepatuhan Wajib Pajak Orang Pribadi. 12(1), 1-9. https:// doi.org/10.22441/ profita.2019.v12.01.001

Mardiasmo. (2016). Perpajakan (2016th ed.). Yogyakarta: CV Andi.

Peraturan Menteri Keuangan RI Nomor 74/PMK. 03 Tahun 2012 Tentang Jangka Waktu Pendaftaran dan Pelaporan Kegiatan Usaha, Tata Cara Pendaftaran, Pemberian, dan Penghapusan Nomor Pokok Wajib Pajak, Serta Pengukuhan dan Pencabutan Pengukuhan Pengusaha Kena Pajak

Peraturan Menteri Dalam Negeri Republik Indonesia Nomor 08 Tahun 2015 tentang Susunan Organisasi dan Tata Kerja Pemerintah Desa.

Putri, R. L. (2016). Pengaruh Motivasi Membayar Pajak dan Tingkat Pendidikan Terhadap Kepatuhan Wajib Pajak Orang Pribadi. Universitas Negeri Yogyakarta.

Rahayu, S. K. (2013). Perpajakan Indonesia: Konsep dan Aspek Formal. Yogyakarta: Graha Ilmu.

Rahman, A. (2010). Panduan Pelaksanaan Adminisratif Perpajakan untuk Karyawan, Pelaku Bisnis dan Perusahaan. Bandung: Nuansa.

Resmi, S. (2014). Perpajakan: Teori dan kasus. Jakarta: Salemba Empat.

Tjahjono. (2006). Pengaruh tingkat kepuasan atas pelayanan perpajakan terhadap tingkat kepatuhan wajib pajak orang pribadi. Universitas Airlangga.

Undang-undang Nomor 28 Tahun 2007 Tentang Ketentuan Umum dan Tata Cara Perpajakan

Undang-Undang Nomor 28 Tahun 2009 Tentang Pajak Daerah dan Retribusi Daerah

Widodo, W. (2010). Moralitas, Budaya dan Kepatuhan Pajak. Jakarta: CV Alfabeta.

Www.pajak.go.id. (2017). Laporan Kinerja Tahun 2017. Retrieved from https://www.pajak.go.id/id/laporan-kinerja-tahun-2017

Yogyakarta.bpk.go.id. (2018). Tagihan PBB P2 Jadi Temuan BPK. Retrieved from https://yogyakarta.bpk.go.id/tagihan-pbb-p2-jadi-temuan-bpk/ 